Acta Universitatis Wratislaviensis No 3836

Anglica Wratislaviensia LVI, Wrocław 2018

DOI: 10.19195/0301-7966.56.3

\title{
Teresa Bruś
}

ORCID: 0000-0003-2845-7195

University of Wroclaw

teresa.brus@uwr.edu.pl

\section{Facepoeia: The Author Becoming a Photographic Subject. The Example of Tadeusz Różewicz}

\begin{abstract}
This paper reflects on the visual practices involving the circulation of portraits of authors in their publications, and in public sphere. The photographic portrait of the author interjects the belief that the presence of the author through and in the image familiarizes and intensifies its subject's presence and declares the author's identity. As a visual paratext, a portrait becomes an autobiographical space of self-invention and self-construction. I wish to illustrate these processes by focusing on Tadeusz Różewicz's (1921-2014) complex ways of accessing visibility and manners of "fixing" his identity in the collaborative work he produced with the photographer Adam Hawałej under the title Rubbish Dump (2015).
\end{abstract}

Keywords: writer's images, self-portrait, paratext, visibility, photography and literature, Tadeusz Różewicz, Adam Hawałej

in the past one could leave for the desert now there's a need to be ever present

Tadeusz Różewicz, "Non-stop show"1

This paper reflects on the practice of photographic recording and the circulation of private and public images of authors in their texts and as separate publications.

1 Translated by Joanna Trzeciak in Sobbing Superpower (119). Trzeciak's translation of Różewicz's Selected Poems (published in 2011 by W.W. Norton) are the latest translations of Różewicz's poems. The volume includes a number of poems omitted from the earlier shorter selected edition New Poems translated by Bill Johnston (published in 2007 by Archipelago Books). The major collections of the poet's work include Tadeusz Rózewicz: They Came to See a Poet with translations by Adam Czerniawski (published in 2004 by Anvil Press Poetry), the bilingual Tadeusz Różewicz: Recycling translated by Tony Howard and Barbara Plebanek (published in 2001 by Arc Publications) and Tadeusz Różewicz: Selected Poems translated by Adam Czerniawski, Richard Sokolski, Barbara Bogoczek and Tony Howard (published in 1995 by Wydawnictwo Literackie). When a translation is not available I provide my own. 
I attempt to consider this popular phenomenon by highlighting strategies confirming the openness of a performing multiplicitous subject who intensifies his or her presence in culture through (self-)images authorized and reconciled by the proper name and connections with the work produced. I will show how photographic images of Tadeusz Różewicz amplify the Polish writer's self-resonance, and how as public and private "epitexts" 2 they reinforce struggles or "tournaments" with his faces. ${ }^{3}$

For Różewicz the human face is one of the most complex and central figures. As a vulnerable zone of contact with the world and with the self, it is at the same time a unique formula for identity-testing, though not for identity-affirmation. We can only transgress this "land so small that you can contain it in your hands or cover it with them" [trans. T.B.] (Opowiadania: 8). Once singular, once plural, it evades capture. Like a landscape or image, as he says in his story "The Face," it promises surfeit, multiplicity and change. It seduces into relationships of collusion, some fusion, perhaps self-knowledge and self-enlargement. But it never coalesces into any substantial microworld. Its contours disappear and so do illusions of stabilizing relationships. One of his speakers recognizes that "all around are your faces / their features / will never be reproduced" (Sobbing: 108). Różewicz can see faces in a very sharp focus and from close-up. Zooming in on their expressions, as he does in case of his Mother, he looks for the particular and the authentic. ${ }^{4}$ The faces encountered by his "poet from Radomsk," his autobiographical persona, lack transparency and definition. False and blurry, white and dry, they emerge as estranging surfaces. At times they invite inscription and proximity, but in the end they disavow connection. Fragmented, cut, pained, deformed, and marked, they disturb with threats of deregulation, disintegration, destabilizing identity crises, and even the destruction of social and personal lives. Often, the potential truth of the telling expression of the face hides in muddled mirror reflections or becomes re/formed in memory.

Hence the poet's repetitive invocations of consolidating portraiture, visual and verbal. In a deceptively simple poem "Homework" from the volume Recycling (1996) he directs attention to the difficulties with portraying a person. The anxious and resigned speaker of the poem invites a fellow young poet to look at his own face, to describe it and to share its "varied moods" with the poet. He has "not read a good self-portrait in Polish poetry," he says, and so challenges

${ }^{2}$ Epitext is a term coined by Gérard Génette in his Paratexts (fr. Seuils) and used to refer to the borderlands or portals of literary texts, the off-texts which reinforce and adorn the text. Epitext is a strategy working from outside of the book (e.g., in the form of interviews with the author), in other words it is a paratext materially not attached to the book. Inspired by Génette, I will include in this category photography and other visual material often of paramount importance to the author's oeuvre.

3 The nice phrase "the tournament with my face" comes from a poem by Zbigniew Herbert "Mr Cogito looks at his face in the mirror" (55).

4 On this point see my paper: Bruś 2011. 
the young poet to confront the impossibly difficult task, to "describe your face" (Tadeusz Różewicz: They: 259). The locus of signification, unlike topographical or metaphysical loci, cannot be seen by the individual, nor can this individual singlehandedly render him/herself in the form of a good portrait. ${ }^{5} \mathrm{He}$ gives hints to the reader of the face to ignore the environs, "Paris / Lwów and Kraków," and other figures like an "angel" (Tadeusz Różewicz: They: 259) and to face the face not in mirror reflections ${ }^{6}$ but captured "from memory," from the direct though possibly imprecise experience of having seen a person in the flesh. Should a "good portrait" be mimetic and creative, framing the particular and the unique about the person as well as identifying the un-reflected and un-embellished truth, while also attaining a level of attraction? Szczukowski observes that, above all, the call to "describe" directs us to literature and its capacity to ask questions about identity, to test our strengths of recovery (35). The poet's comment about lack of good self-portraiture in Polish poetry communicates the expected failure of poets, or possibly the failure of the Polish language. Unlike painterly portraiture, literary self-portrayal allows for "fragmentariness, uncertainty and a relative character of the created image" (Michałowski 315) and so it often compensates expression. The poet's challenge to describe a person is thus a provocation. As a form of intimate paratext, ${ }^{7}$ an internal dialogue about the poet's perpetual failure to consolidate the self in a summative portrait, the poem can also be read as a projection. The ensuing slips into another, more stabilizing medium, into photographic strategies of portraying, relocate visual descriptions into a field of relational alloportraits, including an interaction with other positions. I will return to this issue addressing "rubbish dump" photographs of Różewicz by Adam Hawałej.

Despite his concerns, Różewicz attempts to satisfy our visual pleasure to look at the poet's faces. In an autobiographical introduction recollecting his ID mugshot from 1945, with a white collar, a tie, and one ear showing, he detects a subjectifying difference, the shadow of a smile. Elsewhere, against the convention of an official image, he declares he is "a man of smile" (Przemówienie n.p.). He uses this empathetic identification to draw our attention to the unhappy memories of past experiences. He says that his "biography was coming to an end / on several occasions / some better some worse" (Tadeusz Różewicz: They: 165). At the same time his poetic life sketches contain "still a few blank lines" and room for the deletion and addition of "a few more words" (Sobbing: 107). In the past, we read, when "They came to see a poet" what

5 A point made by Dariusz Szczukowski in his study "O kilku motywach narcystycznych w twórczości Tadeusza Rożewicza" [On narcissistic motifs in T.R.'s oeuvre] in Tadeusz Różewicz i obrazy [T.R. and images] as well as in his polemical book Tadeusz Różewicz wobec niewyrażalnego [T.R. and the ineffable].

${ }^{6}$ In Tadeusz Rożewicz wobec niewyrażalnego [T.R. against the ineffable] Szczukowski devotes his critical attention to a persuasive analysis of the nature and role of mirror reflections in Różewicz's poetry. The mirror, he says, is used by Różewicz to reveal his self-portraiture, problems of the constitution of the self, and the ontological status of representation (9).

7 See Génette 1987: 14. 
they saw was "... a man / sitting in a chair / hiding his face" (Sobbing: 151). He notes moments when he was not able to shore up difficult fragments, when completion was necessary, and so "in the familiar portrait / a new ambiguous feature has appeared / startling and compelling" (Tadeusz Różewicz Selected: 75). In "Dismantled" he goes further declaring boldly: "I don't comprise a whole I've been broken and dismantled / who will stoop over and take an interest in these fragments" (Sobbing: 83). Różewicz will keep trying to counter the disintegrating forces and voices within by, for example, creating lists as strategies of portrayal. He will try to break the regime of form and allow hybridity and collage to assimilate voices and traces of other presences. He will include but also negate: "I am not a professor, nor an adjunct, not even an assistant ... I am only a poet" (Różewicz. Bez tekstu). He will dream of being able to make one photograph out of all his photographs: "from a thousand portraits — one face" (Olek: 5). Expanding his rhetoric of self-identification, he will return to his face. Therefore, it seems that to fathom Różewicz we should keep his face in focus, even though his face is not always an element of trust for him.

The poetic project of creation of the self-identifying self-portrait evokes a lack of clarity of vision: "the face I see / I saw at the outset / unable to foresee" (Poezje: 299). Poetic images are pregnant with the past. Photography, says the poet, "takes only the present tense of the human being" (Olek: 3). A "mobile" subject who has "given up on the wholes" the first condition of further life, he says, is to "stay still" and not allow him/herself "to be torn away from the landscape from image". He says he wants to "preserve everything 'everything" (Opowiadania: 447). Różewicz felt that "one of the miracles of the world", photography, allows us to "touch the time in which we live and pass" (Olek: 3 ) and to preserve our presence. Allowing himself to pose (and play) in front of friendly cameras of, for example, Elżbieta Lempp, Janusz Drzewucki, Zbigniew Kulik, Jerzy Olek, and Janusz Stankiewicz ${ }^{8}$, Różewicz displays the presentiment of his face (often smiling) and his body. While in his poetry the face metamorphoses into a disappointing and anxious form, in his photographic portraits, we detect self-assurance. Różewicz the photographed subject complies with the photographic convention to look content.

In photographs of Różewicz by his devout photographer friend Adam Hawałej from a co-authored volume Rubbish Dump ${ }^{9}$ (2016), readers recognize him not

8 Elżbieta Lempp is the author of Krajobrazy literackie. Fotografia 1985-2007 [Literary landscapes: Photography 1985-2007] containing portraits of major Polish literary figures. Różewicz's formal, stylized portrait appears on a full page with his signature. Drzewucki and Stankiewicz befriended Różewicz. Drzewucki shares the experience in an article "Fotografie Tadeusza Różewicza. Poeta nie odchodzi" in Rzeczpospolita of March 2, 2017. Zbigniew Kulik is the author of a photographic album Różewicz in The Karkonosze Mountains (2011). Jerzy Olek shares his conversations on photography with Różewicz in online journal e-Znaczenia: Kultura. Komunikacja. Społeczeństwo.

9 Witold Kanicki explains that the series of photographs has appeared under different titles but that Adam Hawałej, the photographer, insisted that the series should appear with the commentary to the photographs - a series that was a "happening," and should be called Różewicz at the Rubbish Dump (148). 
in formal "up-market" social portraits, but in a series of over fifty random shots taken, most likely, in one day in 1989 and showing the acclaimed "poet of the rubbish dumps," on a short walk to a dump in his neighbourhood and back home. This self-orchestrated "happening," published decades after the photographs had been taken, ${ }^{10}$ as a book and escorted with excellent critical essays ${ }^{11}$ and five wellknown and acclaimed poems ${ }^{12}$ is a posthumous publication, is an iconic posthume epitext. ${ }^{13}$ To such a category belong the video images and interviews from the 2018 exhibition in Wrocław under a telling title Różewicz. Without a Text. Różewicz's image in a large mural in the centre of Wrocław, the city where he lived until his death in 2014, is a social portrait claiming the public space to commemorate a grand social figure. We can navigate through such epitexts posing questions about the evolution of poetic ideas of the identity of a poet, and how most recent visual projects not only assert a poet's status as an important cultural figure but also revive his poetry. For those who have not read a good self-portrait in Polish poetry, photography and other media offer a new territory of self-staging and creation, an environment in which photography itself to "reclaim life" (Olek: 3). Intermediality, as Dominik Antonik notes aptly, empowers literature to break through barriers and reinforce communication with the audience (140).

Różewicz found rubbish dumps full of life. He always lived at rubbish dumps, by rubbish dumps, over rubbish dumps. He wrote about rubbish and fought with the system to remove rubbish from his sight (Różewicz. Bez tekstu). In Hawałej's photographs collected in their collaborative Rubbish Dump Różewicz re-appears as a performer of the dumps. In this very simple sequence what seems noteworthy is that the Poeta Emeritus, having taken his rubbish out, having cleaned up what needed ordering, smiles. Content to be thus memorialized, in black and white photography, he bids farewell in what Pierre Bourdieu called the "festive aesthetics (...) of communication with others and with the world" (94). To "the rubbish — tip of history" and "the rubbish - tips of poetry," resonating in the fourth poem in the publication, ${ }^{14}$ he added essential compost - a heap of his photographic images.

10 Two of the "rubbish dump" shots had been used in flyleaves of the 1991 volume Plaskor$z e z ́ b a$ [Bas-Relief] against images in which Różewicz poses as an Olympian poet. In 2011 Hawałej included three of "rubbish dump" shots in his Różewicz w obiektywie Adama Hawałeja [Różewicz as Seen by Adam Hawałej].

11 These include Jacek Łukasiewicz's "Wyrzucanie śmieci”, Andrzej Skrendo’s "Czynny zanik”, Witold Kanicki’s “Tadeusz Różewicz idzie na śmietnik” and an interview with the photographer "Pogłębianie życia".

12 The "recycled" poems are: "Dopełnienie" [Completion] (1960), "Decybele" [Decibels] (1969), "Przesypywanie" [That Rustle] (1979), "Nagle" (1983) [Suddenly], "Widziałem go" [I Saw Him] (1998). The themes of refuse, access, and transformation unite these poems.

13 Génette's term, which he defines as all the messages that are situated outside of the book but which reference it after the death of the author (11). It needs to be pointed out that Génette does not dwell on the visual aspect of paratexts, in which category texts reside, but he does recognize that visuals as paratexts constitute an "immense continent" (409).

14 Translation by Czerniawski in Tadeusz Różewicz: They Came to See a Poet (229). 
Speaking of "branding" of authors, Dominik Antonik identifies such projects as interactive actualizations of the brand (143).

Over the centuries psychological and economic developments have changed the status of public images of writers as social figures. Photography, closest to the idea of the direct way of casting light on the subject, has been credited with the power not only to record, but also to mediate knowledge. Many critics argue that the alliance with photography has greatly contributed to the reinforcement of the presence of literature in the public life and, more importantly, to the elevation of literature as a potent cultural force. In the new intermedial spaces writers, says Antonik, have become directors promoting their social aspirations and creating contexts for creative reception of their works (145), making literature accessible beyond the boundaries of the text.

According to François Brunet, photographing writers is a practice within what is by now the very well-established and expanding "industry of photographing literature". Photographic portraits produced and circulated on massive scale in the $19^{\text {th }}$ century have become a "staple of literary publishing and social columns" since the 1970s (128-131). Increasing in importance not only due to public interest in the lives of micro-societies but also due to strengthening integration of literature and photography, portraits of writers have contributed to the public visibility of authors in formal and in intimate contexts. Photography has also granted the authors an experience of "accession to visibility of their faces and bodies" (115). In the mid-twentieth century "the mainstream picture press greatly contributed to the iconicization of writers by regularly featuring their portraits, their interiors and sometimes their hobbies or vacation habits" (Brunet 2013: 125). Authors' images appear as fixed iconic codes but also, more and more, as casual shots correcting celebratory and solemn public images.

Images of authors have revealed webs of relationships between writers and photographers, friendships solidifying the complexity of the genre of portraits of artists. In the author-photographer dyad, a photographer can use the author's image to create a personal artistic genealogy, to inscribe him/herself into a different medium, to become a public figure - a writer's memorialist. In Różewicz w obiektywie Hawałej, however, testifies to an intimate link that defined his life: "I have had the honour of accompanying him [Różewicz] in different walks of life — and I regret that I had only known him for twenty-five years" (140). This candid 2011 album containing ninety-three photographs records friendship in which the photographer says he only participated in ideas and staging that were designed by the poet: "Tadeusz Różewicz was playwright, director, and occasional actor in one" (140). Hawałej was the ancillary figure, not the agent.

As a vocation photography pursued and acknowledged by many writers has strengthened the link between the two arts, leading to revelations of new meanings emerging from the interactions of both. For example, a large volume of Philip Larkin's photographs published in 2015 as The Importance of Elsewhere has been 
received by critics as an essential complement of the poet's work, not only beautifully capturing Larkin's subjects - the everyday life of the English — but also deepening our readings of Larkin's poetry. ${ }^{15}$

It is true that domestic and intimate images can "lead to coveted media bookings" (Miller), to attention that sometimes is greater than authors' circulation, and, paradoxically, to mystification. In the 1950s, responding to images of the "writer on holiday" type, Roland Barthes detected contradictory "eternalizing" and differentiating impulses informing the interest and distribution of personal images of authors: on the one hand the "proletarianization" of writers in quasi-natural settings like holiday resorts, presenting them as ordinary members of society, and on the other hand the imposition of "the glamorous status which bourgeois society liberally grants its spiritual representatives" (29). Writer's images, Barthes argues, do not enhance individual characteristics. They abuse them by entrenching them in a status Barthes identifies as that of "superman": "a kind of intrinsically different being which society puts in the window so as to use to the best advantage the artificial singularity which it has granted him" (30). What Barthes notices is that the seemingly fraternal images, rather than bridging the gap between the writer and the ordinary reader, accentuate it. The gap "from eye to page," in Larkin's words, becomes more pronounced by the injection of fraternal proximity. Confidences such as the exposition of "a good fleshy body" and surroundings revelatory of the writer's tastes do not demystify, but rather emphasize for Barthes "the whole mythical singularity of his condition" (31). Undoubtedly, he would classify Różewicz as Seen by Hawatej as a perfect example of this phenomenon. Barthes displays his unease: "For I cannot but ascribe to some superhumanity the existence of beings vast enough to wear blue pyjamas at the very moment when they manifest themselves as universal conscience" (31). The "spectacular alliance of so much nobility and so much futility" is generative because we continue to credit the writer's work with "miraculous" qualities (31). Barthes's critique, typically attentive to the rhetoric of clothing, alerts us to processes of social identification at work in acts of portrayal. Różewicz, orchestrating his photographic happening with Adam Hawałej, does not wear pyjamas but rather his very ordinary coat and hat. When designing documentation of one of the most banal activities - taking the rubbish out - Różewicz is aligning "nobility" and "futility" consciously and happily. A great poet at the rubbish dump is a paparazzi exercise in self-portrayal, a contradictory paratext to Różewicz's poetic self-portrayals. To poetic portraits it adds public images which, like rubbish itself, speak of the scattered and inconsiderate nature of the public sphere, and which like rubbish, may one day turn out to reveal some unexpected facets.

Viewers implant their expectations and pleasures in photographs of social figures. Readers generally "want to see the face behind" the works they have read

15 See, for example, Mark Haworth-Booth's Foreword to this publication by Richard Bradford. 
or they are going to read. They expect that they will participate in relationships that are revealing of the creative subjects, and they seek to establish some corporeal contact with the author. Publishers respond to these wishes by interjecting literary texts with portraits of writers on dust jackets or on promotional posters, disseminating emblems of the faces of writers, ${ }^{16}$ supporting in this way the economy of affect.

Writers often feel that their self-images create horizons of expectations. Jhumpa Lahiri in an autobiographical essay The Clothing of Books suggests that without the visual garb a book "lacks a face." A writer's photographic portrait presents the face which, like other visual components, says: "look at me." As readers, we respond to a look which is pleasing or distracting, seductive or repulsive. This look is often the first act of recognition. Like a tourist, says Lahiri, the reader before reading, before entering the text, begins to inform and orient herself. S/he begins interpretation by reacting to the distinct information that the photographic portrait makes available. Through the act of interpreting, readers can rely on illustration to test the oppositions between truth or falsity, and also to question their own investment in the text.

Writers have exhibited various attitudes towards circulation of their images, ${ }^{17}$ attitudes ranging from resistance to enthusiasm, and various aesthetics ranging from "aesthetics of disappearance" (Virilio in Brunet 2013: 129) to aesthetics of excessive presence. For many writers in the early stages of photographic portraiture, Brunet illustrates, "guarded behavior was guided not only by frustration with their photographic images but by a more political reaction against the pressure to have their faces publicized" (116). Feeling vulnerable, writers often treated photographic portraits as another territory of public scrutiny and possibly misinterpretation. Others, like Modernist writers and the Surrealist group "for whom iconicization and publicization of their selves seemed quite welcome, took an active part in the picture-making or in the circulation of images and thus willingly contributed their images to the ongoing redefinition of literature's public role - indeed to the elevation of literature to the status of new religion" (117). The author-photographer dyad continues to fertilize modern culture.

Self-portraying, "a major, if not the exclusive theme in art" (Morawińska), shows that identity cannot be reached. As a certain zone indécise, or a liminal vestibule in Gérard Génette's words, authors' self-images or their portraits testify to

16 The photographer Chris Close, for example, supports such actions by capturing faces of authors at literary festivals. His 2017 display featured 500 authors in a spontaneously curated show presented a day after festival readings and shown at open air walkways at Charlotte's Square Gardens in Edinburgh.

17 The photographer Gisèle Freund, recognized as one of the prominent photographers of writers in the $20^{\text {th }}$ century, the first photographer to capture James Joyce in colour photographs, says that by their trade writers "know how to pose". Her experience with writers of the period was, she says, that the anxiety that "they will survive more because of their works than because of any portrayal of their physical form, which temporarily harbored their anxiety" (7). For more references on self-promotion by writers see Marketing Modernisms (eds. Kevin J.H. Pettmar and Stephen Watt). 
that condition, equipping the literary texts but not belonging to the narratives. They are paratexts "participating in indeed embodying literary projects" (Brunet 2013: 138). A photographic work like Rubbish Dump is an important example of the fruitful alliance of literature and photography which, Brunet argues, is becoming new literature. The synergy between photography and literature within which we can locate questions about authors' self-images and in which space for self-invention and self-construction expands, interjects into these projects the belief that the presence of the author through the image and in the image, this most democratic and profitable form of representation and dissemination, can confirm and redeem his cultural significance. Rubbish Dump, the posthume message for the reader both presents and recommends Różewicz the poet and his poetry for further cultural recycling.

\section{References}

Antonik, D. 2014. Autor jako marka: literatura w kulturze audiowizualnej społeczeństwa informacyjnego. Kraków: Universitas.

Barthes, R. 1972. Mythologies. Lavers, A. (trans.). New York: Hill and Wang, 1972.

Bourdieu, P. 1990. Photography: A Middle-brow Art. Whiteside, S. (trans.). Stanford: Stanford University Press.

Bradford, R. 2015. The Importance of Elsewhere: Philip Larkin's Photographs. London: Frances Lincoln.

Brunet, F. 2013. Photography and Literature. London: Reaktion Books.

Bruś, T. 2011. "Still Lives: Photographic Portraits of the Mother in Roland Barthes and Tadeusz Różewicz.” Prose Studies 33:1. 62-73.

Freund, G. 1989. The Poetry of the Portrait: Munich: Schirmer Art Books.

Génette, G. 1987. Seuils. Paris: Éditions du Seuil.

Herbert, Z. 2000. Poezje wybrane / Selected Poems. Carpenter J. and B., C. Miłosz and P.D. Scott (trans.). Kraków: Wydawnictwo Literackie.

Lahiri, J. 2016. The Clothing of Books. New York: Vintage.

Michałowski, P. 1996. "Niewyrażalność siebie i poetycki autoportret negatywny." In: Bolecki, W. and E. Kuzma (eds.). Literatura wobec niewyrażalnego. Warszawa: Instytut Badan Literackich PAN. 313-327.

Miller, J. 2017. “A Picture Says It All or Does It?.” Daily Beast. 14 October. n.p.

Morawińska, A. 2005. "Introduction.” In: Czubak, B. Egocentryczne, Niemoralne, Przestarzate. Wspótczesne wizerunki artystów. Warszawa: Zachęta Narodowa Galeria Sztuki. 3.

Olek, J. “Tadeusz Różewicz: ...opisuje siebie, i tylko siebie...” E-Znaczenia. Kultura. Komunikacja. Spoleczeństwo. www.e-znaczenia.pl/?p=1073/.

Różewicz. Bez tekstu. [Exhibition]. Wystawa w Muzeum Pana Tadeusza Zakładu Nrodowego im. Ossolińskich. 15.12.2017-11.03.2018.

Różewicz w obiektywie Adama Hawałeja. 2011. Wrocław: Wrocławski Teatr Współczesny.

Różewicz, T. 1994. Opowiadania. Wrocław: Wydawnictwo Dolnośląskie.

Różewicz, T. [2007]. Przemówienie wygłoszone 8 października 2007 r. w Akademii Sztuk Pięknych we Wrocławiu z okazji przyznania doktoratu honoris causa. Wrocław.

Różewicz, T. and A. Hawałej. 2016. Śmietnik. [Rubbish Dump]. Wrocław: Wrocławskie Wydawnictwo Warstwy. 
Różewicz, T. 2011. Sobbing Superpower: Selected Poems of Tadeusz Różewicz. Trzeciak, J. (trans.). New York: WW Norton.

Tadeusz Różewicz. Poezje wybrane. 1995. Czerniawski A., R. Sokolski, B. Bogoczek and T. Howard (trans.). Kraków: Wydawnictwo Literackie.

Tadeusz Różewicz: They Came to See a Poet. 2014. Czerniawski, A. (trans.). London: Anvil Press Poetry.

Stankowska, A., M. Śniedziewska and M. Telicki (eds.). 2015. Tadeusz Różewicz i obrazy. Poznań: Wydawnictwo Poznańskiego Towarzystwa Przyjaciół Nauk.

Szczukowski, D. 2008. Tadeusz Różewicz wobec niewyobrażalnego. Kraków: Universitas. 